慶應義塾大学学術情報リポジトリ

Keio Associated Repository of Academic resouces

\begin{tabular}{|c|l|}
\hline Title & Radiobromination of aromatic compounds by cleavage of aryl-tin bonds \\
\hline Sub Title & \\
\hline Author & $\begin{array}{l}\text { Adam, Michael J.( Honma, Yoshio) } \\
\text { Ruth, Thomas J. } \\
\text { 本間, 義夫 } \\
\text { Pate, Brian D. }\end{array}$ \\
\hline Publisher & 共立薬科大学 \\
\hline Publication year & 1985 \\
\hline Jtitle & $\begin{array}{l}\text { 共立薬科大学研究年報 (The annual report of the Kyoritsu College of } \\
\text { Pharmacy). No.30 (1985. ) ,p.80-81 }\end{array}$ \\
\hline JaLC DOI & \\
\hline Abstract & \\
\hline Notes & 抄録 \\
\hline Genre & Technical Report \\
\hline URL & https://koara.lib.keio.ac.jp/xoonips/modules/xoonips/detail.php?koara_id=AN00062898-0000003 \\
\hline & $0-0080$ \\
\hline
\end{tabular}

慶應義塾大学学術情報リポジトリ(KOARA)に掲載されているコンテンツの著作権は、それぞれの著作者、学会または出版社/発行者に帰属し、その権利は著作権法によって 保護されています。引用にあたっては、著作権法を遵守してご利用ください。

The copyrights of content available on the KeiO Associated Repository of Academic resources (KOARA) belong to the respective authors, academic societies, or publishers/issuers, and these rights are protected by the Japanese Copyright Act. When quoting the content, please follow the Japanese copyright act. 


\title{
Radiobromination of Aromatic Compounds by Cleavage of Aryl-Tin Bonds*
}

\author{
Michael J. Adam**, Thomas J. Ruth**, Yoshio Homma and Brian D. Pate**
}

Radiobrominated compounds have been proposed as useful tools in studies of nuclear medicine and biochemistry particularly as receptor binding radiopharmaceuticals. Although a variety of reports have been published on bromination methods, most of these techniques have limitations. These methods usually rely on the direct electrophilic bromination of aromatic compounds using bromide oxidized in-situ with an oxidant such as chloramine- $\mathrm{T}$ (CAT) or N-chlorosuccinimide (NCS). These methods usually produce low yields and/or mixtures of ring isomers.

It is well known that aryl-tin bonds can be cleaved selectively by electrophilic halogenating agents in the presence of alkyl-tin bonds. Following this fact, we synthesized a series of aryl-tin compounds by first metallating the appropriate bromo- or iodoprecursors, via lithium-halogen exchange with $n$-BuLi, and subsequent transmetallation using tri- $n$-butyltin chloride. All of the tin substrates were brominated with "cold" $\mathrm{NaBr}$, to determine chemical yields, and then with $\mathrm{NH}_{4}{ }^{82} \mathrm{Br}$ and $\mathrm{NCA} \mathrm{Na}^{77} \mathrm{Br}$ to determine radiochemical yields at different levels of specific activity. Both chloramine- $T$ (CAT) and N-chlorosuicinimide (NCS) were used as oxidants in this study. Bromination chemical yields ranged from $78.8 \%$ to $96.9 \%$ with reaction times ranging from $5-35$ minutes. In general, the bromination rates with $\mathrm{NaBr} / \mathrm{NCS}$ were rather slow and yields lower than those with $\mathrm{NaBr} / \mathrm{CAT}$. The yields from reactions employing CAT/ $\mathrm{NaBr} / \mathrm{HCl}$ were shown to be very dependent upon the concentration of $\mathrm{HCl}$.

A stimulation phenomena was observed when using $\mathrm{NaBr} / \mathrm{CAT}$, with no $\mathrm{HCl}$, when the mixtures were cooled to dry ice temperature. Yields increased from about $10 \%$ before cooling to $40 \%$ after cooling as seen in the glc chromatogram. This affect was seen for all of the tin substrates and may reflect an increase in concentration of reagents into the ethanol portion of the solvent mixture as the aqueous component freezes.

Radiobromination reactions with ${ }^{82} \mathrm{Br}$ gave excellent results with average radiochemical yields being greater than $90 \%$. Again, reactions utilizing $\mathrm{CAT} / \mathrm{HCl}$ were faster than reactions using NCS. When NCS was employed the reaction times were, as expected, shorter for the highly activated systems than for any of the other substrates. Times ranged from 5 minutes for the veratrole and anisole systems to 45 minutes for the chloro derivative. Two control reactions were performed whereby fluorobenzene and toluene were brominated under the same conditions as used for the stannylated

* Int. J. Appl. Radiat. Isotopes 36, (12), 935-937 (1985) に発表

** TRIUMF. University of British Columbia 
substrates. After 5 minutes using $\mathrm{CAT} / \mathrm{HCl}$ only $33 \%$ and $5 \%$ of the para-fluoro products were detected. Running these reactions for a longer time only caused the yield to decrease, in the case of fluorobenzene, and to increase only slightly for the toluene derivative.

Reactions with $\mathrm{NCA}^{77} \mathrm{Br}$ also gave very high radiochemical yields. Under the conditions used in these reactions there was no apparent difference in reaction rates when using either NCS or CAT. This may have been due to the higher concentration of substrate and the higher molar ratio of tin substrate to oxidant and bromide. All radiochemical yields except that of the chlorinated compound were $90 \%$ or higher. For the chlorinated compound NCS/HOAc gave the best results with a yield of $82 \%$. The chromatogram reveals an unidentified impurity component making up $18 \%$ of the total yield. 